\title{
Comparative analysis of the effect of vernonia amygdaline on subsea transmission pipeline
}

Nitonye SAMSON, Thaddeus C. NWAOHA, Umoh Ofonime EMMANUEL

DOI: 10.30464/jmee.2018.2.4. 269

Cite this article as:

Samson N., Nwaoha T. C., Emmanuel U. O. Comparative analysis of the effect of vernonia amygdaline on subsea transmission pipeline. Journal of Mechanical and Energy Engineering, Vol. 2(42), No. 4, 2018, pp. 269-276.

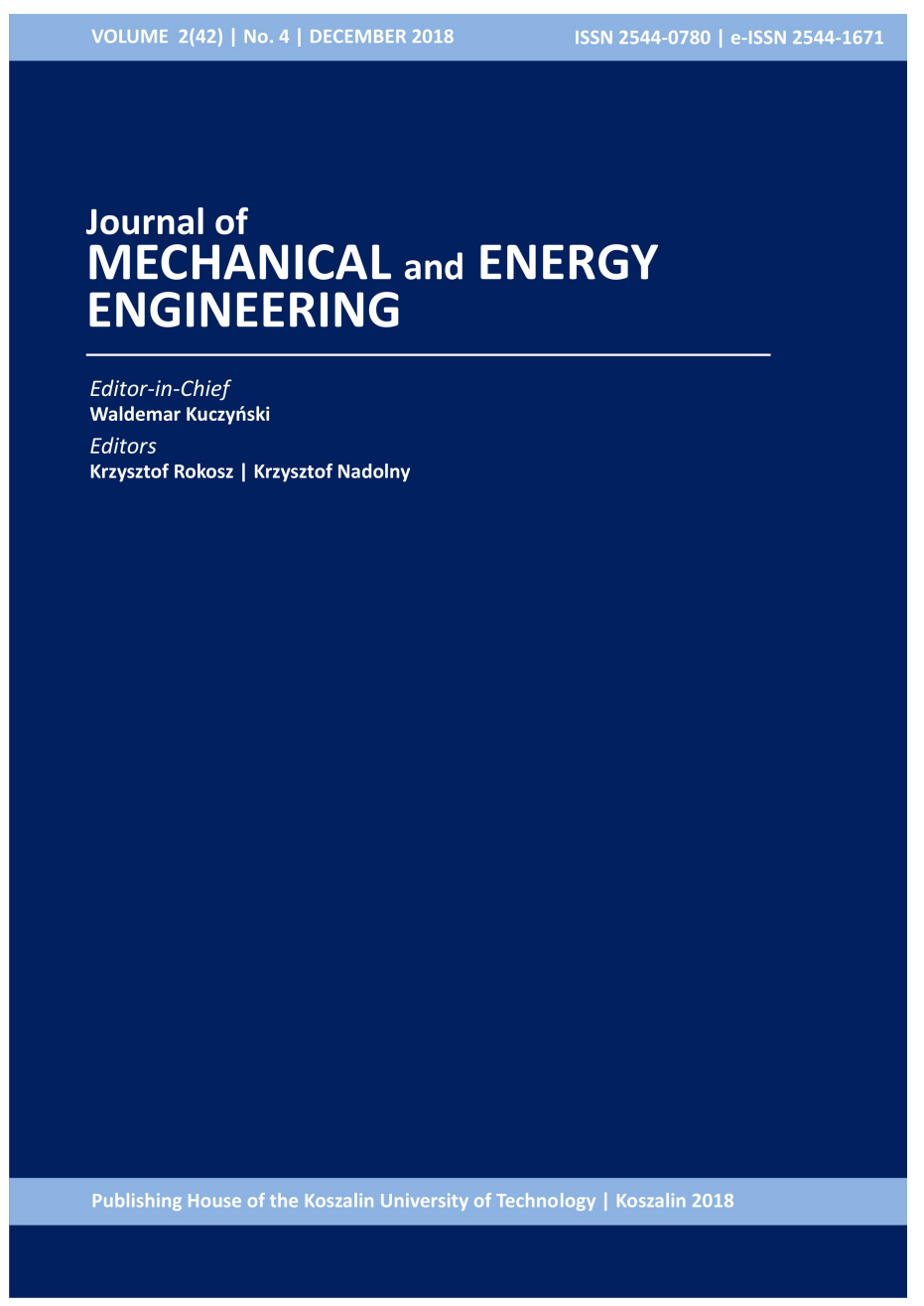

Journal of Mechanical and Energy Engineering

Website: jmee.tu.koszalin.pl

ISSN (Print): 2544-0780

ISSN (Online): 2544-1671

Volume: 2(42)

Number: 4

Year: 2018

Pages: 269-276

Article Info:

Received 6 November 2018

Accepted 12 December 2018

\section{Open Access}

This article is distributed under the terms of the Creative Commons Attribution 4.0 (CC BY 4.0) International License (http://creativecommons.org/licenses/by/4.0/), which permits unrestricted use, distribution, and reproduction in any medium, provided you give appropriate credit to the original author(s) and the source, provide a link to the Creative Commons license, and indicate if changes were made. 


\title{
COMPARATIVE ANALYSIS OF THE EFFECT OF VERNONIA AMYGDALINE ON SUBSEA TRANSMISSION PIPELINE
}

\author{
Nitonye SAMSON ${ }^{1}$, Thaddeus C. NWAOHA ${ }^{2^{*}}$, Umoh Ofonime EMMANUEL ${ }^{3}$ \\ ${ }^{1}$ Department of Marine Engineering, Rivers State University, Port Harcourt, Rivers State, Nigeria. \\ ${ }^{2 *}$ Department of Marine Engineering, Federal University of Petroleum Resources, Delta State, Nigeria, \\ nwaoha.thaddeus@fupre.edu.ng. \\ ${ }^{3}$ Department of Mechanical/Marine Engineering, Niger Delta University, Amassoma, Bayelsa State, Nigeria.
}

(Received 6 November 2018, Accepted 12 December 2018)

\begin{abstract}
Subsea transmission pipelines (STP) are designed to transport liquids, gases or solid/liquid mixtures over some distances. STP are buried underground or submerged in water for transportation of natural oil and gas $(\mathrm{O} \& \mathrm{G})$ products. A Vernonia amygdalina (VA) solution is prepared to act as an inhibitor. The specimens are kept in a workable state. Steps are taken to prepare each specimen. All cuts and sheared edges were ground out to prevent them from becoming sites for preferential attack. The finishing of the specimen surface with grit abrasive paper (sand paper) and rinsing of the specimens in distilled water are carried out. Then, degreasing of specimen in acetone and air-dried are carried out. Upon drying, the specimens are immediately weighed to obtain their initial weights. Twelve specimens are used for the test as follows: 6 Aluminum (Al); and 6 mild steel (MS) samples. With a $2 \mathrm{M}$ concentration of VA solution, the MS and $\mathrm{Al}$ samples are immersed in different plastic containers containing $400 \mathrm{ml}$ of seawater with $\mathrm{pH}$ value of 7.25 with no $(0 \%)$ inhibitor added to it. A $5 \%$ (400ml) of the VA solution is poured into the measuring cylinder for each sample-Al and MS. The specimens are suspended by the strings and completely immersed in the different percentage test media. The same procedure is carried out for each of the different percentages (i.e. 10\%, 15\%, 20\%, and $25 \%$ ) and a total of 12 solutions are set up. The seawater used has $7.25 \mathrm{pH}$. At the end of every week (168 hours), the specimens are removed from the corrosive media. Observation and recording of appearance of the specimen, noting sites are done to analyze the effect of the VA solution on the AL and MS used for the STP. Values are obtained and graphs plotted on weight loss (WL) and corrosion rate (CR) versus the time. It is observed that the VA solution has different effect on the STP at different time and percentage of the VA solution introduced into the environment of the pipe. It was also observed that optimum inhibition of coupons is obtained between $15-25 \%$ of VA solution during the first four weeks of testing. At the fifth week, the inhibitor was gradually losing its effectiveness. This means that more inhibitor needs to be added at regular intervals in order to sustain the effectiveness of the inhibitor.
\end{abstract}

Keywords: pipelines, corrosion, environment, sea water, inhibitors, specimen, VA solution, corrosion rate (CR), weight loss (WL)

\section{INTRODUCTION}

Transmission pipelines (TP) are large complex network of pipelines used in the transportation of natural oil and gas $(\mathrm{O} \& \mathrm{G})$ from one point of origin such as well heads, drill stations and terminals to various distribution centers and storage facilities. TPs are the most efficient and effective means of bulk fluid transportation due to its flexibility of route as compared to rail and tanker system. Large TPs are buried underground or submerged in water for transportation of natural $O \& G$ products from drilling rigs to refineries and filling stations. The history of TPs is dated far back as $400 \mathrm{BC}$, which is about 2500 years ago and these TPs are designed to operate for 
many years unnoticed and without failure. However, they are exposed to unfavorable environmental conditions, thereby making them susceptible to corrosion [1]. Corrosion is a major hazard affecting the operational efficiency of TPs. Due to catastrophic consequences of TPs failure as a result of corrosion, there is need to ensure safety of the TPs during operation. Corrosion reduces the structural integrity of TPs, thus deteriorate it and consequently spill the TPs content to the environment. This work is aimed at doing a comparative analysis on the effects of VA solution on TPs in combating corrosion in metals like Aluminum (AL) and mild steel (MS). It will analyze the various forms of corrosion; describe the basic principles of corrosion of MS and $\mathrm{Al}$; identify the various conditions necessary for corrosion occurrence; determine the effect of inhibitor on corrosion reaction and determine the parameters used for measuring CR [2].

\section{CORROSION}

Corrosion is the destruction of the component of a material gradual as a result of the chemical or electrochemical reactions of this material and its environment. Corrosion is the degradation of material via the interactions with the environment. This could be man-made and natural occurrence. In this work, the main emphasis is to analyse the effect of VA solution on TPs (MS and AL) submerged in seawater of high salinity. TPs can corrode in aqueous environments. The environment acts as the electrolyte and corrosion occur as an electrochemical process. Corrosion can be classified as dry and wet corrosion, chemical and electrochemical corrosion. Most corrosion problems encountered fall into five basic categories such as uniform or general corrosion, localized corrosion, metallurgical induced corrosion, mechanically assisted corrosion and stress corrosion cracking. Known five types of corrosion can be divided into eight forms, which can be visually identified. They include the general or uniform corrosion, galvanic corrosion, crevice corrosion and pitting corrosion [3]. Others are inter-granular corrosion, micro biologically influenced corrosion, erosion corrosion and stress cracking corrosion [3].

Anode and cathode has reactions in a typical galvanic cell as $\mathrm{Fe} \rightarrow \mathrm{Fe}^{2+}+2 \mathrm{e}-$ and $2 \mathrm{e}-+2 \mathrm{H}^{+} \rightarrow \mathrm{H}_{2}$ respectively. In the Electrolyte, it is $\mathrm{H}_{2} \mathrm{O} \rightarrow \mathrm{OH}^{-}+\mathrm{H}+$ $\mathrm{Fe}^{2+}+2 \mathrm{OH}^{-} \rightarrow \mathrm{Fe}(\mathrm{OH})_{2}$. Galvanic corrosion cannot occur without existence of three conditions. The conditions are electrochemically disparate metals must be present; the metals must be in electrical contact, and the metals must be open to an electrolyte [4].

There are various factors that enhance corrosion. Such factors include the presence of an anode and a cathode, a metallic bond, a voltage potential between the anode and cathode and an electrolyte with the presence of oxygen. The basic corrosion cell has these four parts, all of which must exist for corrosion to occur. The nature of metal and nature of exposed environment could be considered as factors that could foster corrosion. In the nature of the metal we must look at the passivity of metal, the purity of the metal, the oxidation potential, over-voltage and the relative area of the anode and cathode amongst others. Furthermore the nature of the environment of exposure will consider the following factors such as the temperature, concentration of Hydrogen ions and the soil corrosivity [5].

Metal corrosion can also occur in fresh water, seawater, salt solutions, and alkaline or basic media. In almost all of these environments, corrosion occurs if dissolved oxygen is present. Oxygen from the air is dissolved using water solution. Familiar corrosion of this type, is the rusting of iron when exposed to a moist atmosphere [6].

$$
4 \mathrm{Fe}+6 \mathrm{H}_{2} \mathrm{O}+3 \mathrm{O}_{2} \rightarrow 4 \mathrm{Fe}(\mathrm{OH})_{3} \downarrow
$$

In this Equation 1, iron combines with water and oxygen to produce an insoluble reddish-brown corrosion product that falls out of the solution, this is depicted by the downward pointing arrow. During rusting in the atmosphere, there is an opportunity for drying the ferric hydroxide dehydrates and forms the familiar red-brown ferric oxide (rust) or $\mathrm{Fe}_{2} \mathrm{O}_{3}$, as shown in Equation 2:

$$
2 \mathrm{Fe}(\mathrm{OH})_{3} \rightarrow \mathrm{Fe}_{2} \mathrm{O}_{3}+3 \mathrm{H}_{2} \mathrm{O}
$$

Similar reactions occur when zinc is exposed to water or moist air followed by natural drying as evidenced in Equations 3 and 4.

$$
\begin{gathered}
2 \mathrm{Zn}+2 \mathrm{H}_{2} \mathrm{O}+\mathrm{O}_{2} \rightarrow \mathrm{Zn}(\mathrm{OH})_{2} \\
\mathrm{Zn}(\mathrm{OH})_{2} \rightarrow \mathrm{ZnO}+\mathrm{H}_{2} \mathrm{O}
\end{gathered}
$$

The resulting zinc oxide is the whitish deposit seen on galvanized pails, rain gutters, and imperfectly chrome-plated bathroom faucets. It also familiarly called 'white rust', a non-protective and even destructive form of corrosion that attacks incompletely passivated galvanized steel material or galvanized components subjected to marine atmospheres [7].

In the three major techniques of combating corrosion such as material selection, environmental control and design features, VA solution will be used as inhibitor to reduce the rate of corrosion in MS and AL. Inhibitors act to slow down the anodic or cathodic reaction by the formation of a protective film on the system, confined in a corrosive environment that need to be protected. Corrosion inhibitors have their limitations and disadvantages such as contamination of the environment; most inhibitors are toxic in nature; can only be used in closed systems and medium with zero flow rates; inhibitors lose their efficiencies with increasing concentration and temperature [8]. 


\section{MATERIALS AND METHODS}

The laboratory test conducted will provide data and facts for the appropriate material selection for use in pipelines installation on offshore structures salt water (seawater) environments, corrosion control and study of corrosion mechanisms. The ASTM G13 standards are employed. The test apparatus include twelve testing specimens, corrosive medium-seawater, VA (bitter leaf) solution, distilled water, plastic bowl, top-loading electronic chemical weighing balance, measuring cylinder, beakers, rubber threads, acetone, wooden sticks. The test specimens to be compared are MS and Al sheets and the shape and size of specimen. The specimen is machined to have a large surface area to mass ratio and a small ratio of edge area to total area is used. A square specimen of dimension $35 \times 30 \times$ $1 \mathrm{~mm}$ is used. A $2.5 \mathrm{~mm}$ hole is bored near the top centre of the specimens. Total surface area of each specimen is given as shown in Equation 5.

$$
A=2(L B+B H+L H)+\left(\pi d H-\frac{\pi d^{2}}{2}\right),
$$

where; $\mathrm{L}=$ length of the specimen $=35 \mathrm{~mm}$;

$H=$ thickness of the specimen $=1 \mathrm{~mm}$;

$D=$ bore diameter $=2.5 \mathrm{~mm}$;

$B=$ breadth of the specimen $=30 \mathrm{~mm} ; \pi=\frac{22}{7}$;

$A=2228.04 \mathrm{~mm}=22.28 \mathrm{~cm}$

The specimens must be kept in a workable state to obtain exact results and the steps taken to prepare each specimen are all cuts and sheared edges were ground out to prevent them from becoming sites for preferential attack, finishing of the specimen surface with grit abrasive paper (sand paper), rinsing of the specimens in distilled water, degreasing of specimen in acetone and air dried and upon drying, the specimen was immediately weighed to obtain their initial weights [9].

\subsection{Number of Specimen and their Labeling}

Twelve specimens are used for the test, comprised of six $\mathrm{Al}$ and six MS samples. In order to immerse the samples into each solution, holes are made at the top sides of the plastic containers and a wooden stick placed across it. The thread is tied through the hole in each samples and placed to the wooden sticks which are marked with their corresponding label and dipped into the corrosive medium in the propulsion of $5 \%$, $10 \%, 15 \%, 20 \%, 25 \%$ and $0 \%$.

\subsection{Preparation of VA Solution and Experimental Procedure}

$1200 \mathrm{~g}$ of bitter leaf is plucked, weighed and crushed. $600 \mathrm{cl}$ of water is added to the crushed leaves. The mixture is put in a filter cloth and squeezed with hand to filter out the active concentration ingredients responsible for corrosion inhibition. This resulted to production of $2 \mathrm{M}$ concentration of VA extract solution. MS and $\mathrm{Al}$ samples are immersed in different plastic containers containing $400 \mathrm{ml}$ of seawater with $\mathrm{pH}$ value of 7.25 with no $(0 \%)$ inhibitor added to it. This is called the control solution. From the $2 \mathrm{M}$ bitter leaves extract solution prepared, $5 \%(400 \mathrm{ml})$ is measured, using a measuring cylinder. The corrosive medium seawater is poured into the measuring cylinder that contains 5\% bitter leaves extract solution. Such exercise is continued until the meniscus of the mixture reached the $400 \mathrm{ml}$ mark. The final solution produced is put into a plastic container. The same 5\% solution is done for two different plastic containers meant for each sample-Al, and MS. Each set of the specimen is looped about the wooden sticks by the aid of the rubber strings. The specimen is suspended by the strings and completely immersed in the different percentage test media. The same procedure is carried out for each of the different percentages of $10 \%, 15 \%$, $20 \%$, and $25 \% .12$ solutions are set up.

The experimental procedure used is seawater of $7.25 \mathrm{pH}$ is obtained from Abonnema water front of Rivers State. At the end of every week (168 hours), steps taken to obtain readings are the specimen is removed from corrosive media, observed and record of appearance of the specimen, noting sites and locations of deposits and variation in types of deposits. Then, clean the specimen with white handkerchief or tissue paper, which is followed by washing of specimen with distilled water and scrubbing of specimen with a soft brush. It is later dipped into acetone, after washing and then removed to air-dry and weighed. Later the specimen is weighed immediately after cleaning. This is recorded as the initial weight. For each of the 12 set ups, the weight loss for each week is obtained by calculating the difference between the initial weight of each specimen and weight after immersion using Equation 6.

$W L \Delta W=($ weight at time, $t=0)-($ weight at time, $t-i)$,

where

$i=1-5$ weeks,

$W=$ weight,

$W L=$ weight loss.

\subsection{Determination of Corrosion Rate}

The mathematical model for calculating the CR is shown in Equation 7 below. The CR is proportional to the mass loss on the pipeline with area, density and time exposure as constant throughout the pipe. The unit CR is $\mathrm{mm} / \mathrm{yr}$.

$$
C_{R}=\frac{K \times W}{A \times T \times D},
$$

where,

$W=$ mass loss $(\mathrm{g}), K=C R$ constant $=8.76 \times 104 A=$ area of specimen $\left(\mathrm{cm}^{2}\right), D l=$ density of MS $\left(\mathrm{g} / \mathrm{cm}^{2}\right)=$ $7.86 \mathrm{~g} / \mathrm{cm}^{3}, T=$ time of exposure in hours and $D 2=$ density of $\mathrm{Al}\left(\mathrm{g} / \mathrm{cm}^{2}\right)=2.7 \mathrm{~g} / \mathrm{cm}^{3}$. 


\section{RESULTS AND DISCUSSION}

The results obtained from the experiment carried out in the previous section are tabulated in Tables 1 to 12. The weight loss and CR rate shown in these results are based on a number of factors.

Tab. 1. Data for WL and CR of Al Sample with 5\% Inhibitor

\begin{tabular}{cccccc}
\hline Code & $\begin{array}{c}\text { Time } \\
\text { (hour) }\end{array}$ & $\begin{array}{c}\text { Initial } \\
\text { weight } \\
(\mathrm{g})\end{array}$ & $\begin{array}{c}\text { Final } \\
\text { weight } \\
(\mathrm{g})\end{array}$ & $\begin{array}{c}\text { Change in } \\
\text { weight }(\mathrm{g})\end{array}$ & $\begin{array}{c}\mathrm{CR} \\
(\mathrm{mm} / \mathrm{yr})\end{array}$ \\
\hline 1A1 & 168 & 2.9290 & 2.9181 & 0.0109 & 0.0944 \\
\hline 1A2 & 336 & 2.9290 & 2.9107 & 0.0183 & 0.0793 \\
\hline 1A3 & 504 & 2.9290 & 2.9105 & 0.0185 & 0.0534 \\
\hline 1A4 & 672 & 2.9290 & 2.9107 & 0.0183 & 0.0396 \\
\hline 1A5 & 840 & 2.9290 & 2.9114 & 0.0176 & 0.0305 \\
\hline
\end{tabular}

Tab. 2. Data for WL and CR of MS Samples with 5\% Inhibitor

\begin{tabular}{cccccc}
\hline Code & $\begin{array}{c}\text { Time } \\
(\text { hour })\end{array}$ & $\begin{array}{c}\text { Initial } \\
\text { weight } \\
(\mathrm{g})\end{array}$ & $\begin{array}{c}\text { Final } \\
\text { weight } \\
(\mathrm{g})\end{array}$ & $\begin{array}{c}\text { Change } \\
\text { in weight } \\
(\mathrm{g})\end{array}$ & $\begin{array}{c}\mathrm{CR} \\
(\mathrm{mm} / \mathrm{yr})\end{array}$ \\
\hline 1S1 & 168 & 6.6576 & 6.6321 & 0.0255 & 0.0759 \\
\hline $1 \mathrm{~S} 2$ & 336 & 6.6576 & 6.6239 & 0.0337 & $0.050 \mathrm{I}$ \\
\hline $1 \mathrm{~S} 3$ & 504 & 6.6576 & 6.6149 & 0.0427 & 0.0423 \\
\hline $1 \mathrm{~S} 4$ & 672 & 6.6576 & 6.6127 & 0.0449 & 0.0334 \\
\hline $1 \mathrm{~S} 5$ & 840 & 6.6576 & 6.6103 & 0.0473 & 0.0281 \\
\hline
\end{tabular}

Tab. 3. Data for WL and CR of Al Sample with $10 \%$ Inhibitor

\begin{tabular}{cccccc}
\hline Code & $\begin{array}{c}\text { Time } \\
\text { (hour) }\end{array}$ & $\begin{array}{c}\text { Initial } \\
\text { weight }(\mathrm{g})\end{array}$ & $\begin{array}{c}\text { Final } \\
\text { weight }(\mathrm{g})\end{array}$ & $\begin{array}{c}\text { Weight } \\
\text { loss }(\mathrm{g})\end{array}$ & $\begin{array}{c}\mathrm{CR} \\
(\mathrm{mm} / \mathrm{yr})\end{array}$ \\
\hline $2 \mathrm{~A} 1$ & 168 & 2.9808 & 2.98 & 0.0008 & 0.006934 \\
\hline $2 \mathrm{~A} 2$ & 336 & 2.9808 & 2.9793 & 0.0015 & 0.006501 \\
\hline $2 \mathrm{~A} 3$ & 504 & 2.9808 & 2.9778 & 0.003 & 0.008668 \\
\hline $2 \mathrm{~A} 4$ & 672 & 2.9808 & 2.9761 & 0.0047 & 0.010185 \\
\hline $2 \mathrm{~A} 5$ & 840 & 2.9808 & 2.8763 & 0.0487 & 0.084426 \\
\hline
\end{tabular}

Tab. 4. Data for WL and CR of MS Samples with $10 \%$ Inhibitor

\begin{tabular}{cccccc}
\hline Code & $\begin{array}{c}\text { Time } \\
(\text { hour })\end{array}$ & $\begin{array}{c}\text { Initial } \\
\text { weight } \\
(\mathrm{g})\end{array}$ & $\begin{array}{c}\text { Final } \\
\text { weight } \\
(\mathrm{g})\end{array}$ & $\begin{array}{c}\text { Change in } \\
\text { weight } \\
(\mathrm{g})\end{array}$ & $\begin{array}{c}\mathrm{CR} \\
(\mathrm{mm} / \mathrm{yr})\end{array}$ \\
\hline $2 \mathrm{~S} 1$ & 168 & 6.2922 & 6.2519 & 0.0403 & 0.1199 \\
\hline $2 \mathrm{~S} 2$ & 336 & 6.2922 & 6.2487 & 0.0435 & 0.0647 \\
\hline $2 \mathrm{~S} 3$ & 504 & 6.2922 & 6.2453 & 0.0469 & 0.0465 \\
\hline $2 \mathrm{~S} 4$ & 672 & 6.2922 & 6.2451 & 0.0471 & 0.0350 \\
\hline $2 \mathrm{~S} 5$ & 840 & 6.2922 & 6.2219 & 0.0703 & 0.0418 \\
\hline
\end{tabular}

Tab. 5. Data for WL and CR of Al Sample with $15 \%$ Inhibitor

\begin{tabular}{cccccc}
\hline Code & $\begin{array}{c}\text { Time } \\
\text { (hour) }\end{array}$ & $\begin{array}{c}\text { Initial } \\
\text { weight }(\mathrm{g})\end{array}$ & $\begin{array}{c}\text { Final } \\
\text { weight }(\mathrm{g})\end{array}$ & $\begin{array}{c}\text { Weight } \\
\text { loss }(\mathrm{g})\end{array}$ & $\begin{array}{c}\mathrm{CR} \\
(\mathrm{mm} / \mathrm{yr})\end{array}$ \\
\hline 3A1 & 168 & 2.6877 & 2.6871 & 0.0006 & 0.0052 \\
\hline 3A2 & 336 & 2.6877 & 2.6853 & 0.0024 & 0.0104 \\
\hline 3A3 & 504 & 2.6877 & 2.6802 & 0.0075 & 0.0216 \\
\hline 3A4 & 672 & 2.6877 & 2.6785 & 0.0092 & 0.0199 \\
\hline 3A5 & 840 & 2.6877 & 2.6719 & 0.0158 & 0.0273 \\
\hline
\end{tabular}

Tab. 6. Data for WL and CR of MS Samples with $15 \%$ Inhibitor

\begin{tabular}{cccccc}
\hline Code & $\begin{array}{c}\text { Time } \\
(\text { hour })\end{array}$ & $\begin{array}{c}\text { Initial } \\
\text { weight } \\
(\mathrm{g})\end{array}$ & $\begin{array}{c}\text { Final } \\
\text { weight } \\
(\mathrm{g})\end{array}$ & $\begin{array}{c}\text { Change in } \\
\text { weight }(\mathrm{g})\end{array}$ & $\begin{array}{c}\mathrm{CR} \\
(\mathrm{mm} / \mathrm{yr})\end{array}$ \\
\hline $3 \mathrm{~S} 1$ & 168 & 6.7667 & 6.766 & 0.0007 & 0.0021 \\
\hline $3 \mathrm{~S} 2$ & 336 & 6.7667 & 6.752 & 0.0147 & 0.0218 \\
\hline $3 \mathrm{~S} 3$ & 504 & 6.7667 & 6.7511 & 0.0156 & 0.0154 \\
\hline $3 \mathrm{~S} 4$ & 672 & 6.7667 & 6.7507 & 0.016 & 0.0119 \\
\hline $3 \mathrm{~S} 5$ & 840 & 6.7667 & 6.7501 & 0.0166 & 0.0098 \\
\hline
\end{tabular}

Tab. 7. Data for WL and CR of Al Sample with $20 \%$ Inhibitor

\begin{tabular}{cccccc}
\hline Code & $\begin{array}{c}\text { Time } \\
\text { (hour) }\end{array}$ & $\begin{array}{c}\text { Initial } \\
\text { weight } \\
(\mathrm{g})\end{array}$ & $\begin{array}{c}\text { Final } \\
\text { weight } \\
(\mathrm{g})\end{array}$ & $\begin{array}{c}\text { Change in } \\
\text { weight }(\mathrm{g})\end{array}$ & $\begin{array}{c}\mathrm{CR} \\
(\mathrm{mm} / \mathrm{yr})\end{array}$ \\
\hline 4A1 & 168 & 2.7698 & 2.7685 & 0.0013 & 0.0112 \\
\hline 4A2 & 336 & 2.7698 & 2.7681 & 0.0017 & 0.0074 \\
\hline 4A3 & 504 & 2.7698 & 2.7680 & 0.0018 & 0.0052 \\
\hline 4A4 & 672 & 2.7698 & 2.7669 & 0.0029 & 0.0063 \\
\hline 4A5 & 840 & 2.7698 & 2.7645 & 0.0053 & 0.0092 \\
\hline
\end{tabular}

Tab. 8. Data for WL and CR of MS Samples with $20 \%$ Inhibitor

\begin{tabular}{cccccc}
\hline Code & $\begin{array}{c}\text { Time } \\
\text { (hour })\end{array}$ & $\begin{array}{c}\text { Initial } \\
\text { weight } \\
(\mathrm{g})\end{array}$ & $\begin{array}{c}\text { Final } \\
\text { weight } \\
(\mathrm{g})\end{array}$ & $\begin{array}{c}\text { Change in } \\
\text { weight }(\mathrm{g})\end{array}$ & $\begin{array}{c}\mathrm{CR} \\
(\mathrm{mm} / \mathrm{yr})\end{array}$ \\
\hline 4S1 & 168 & 6.6391 & 6.6372 & 0.0019 & 0.0056 \\
\hline $4 \mathrm{~S} 2$ & 336 & 6.6391 & 6.6344 & 0.0047 & 0.0069 \\
\hline $4 \mathrm{~S} 3$ & 504 & 6.6391 & 6.6120 & 0.0271 & 0.0268 \\
\hline $4 \mathrm{~S} 4$ & 672 & 6.6391 & 6.6090 & 0.0301 & 0.0224 \\
\hline $4 \mathrm{~S} 5$ & 840 & 6.6391 & 6.5890 & 0.0501 & 0.0298 \\
\hline
\end{tabular}

The values of the above tables are plotted in a graph of WL against time and CR against time as shown in Figures 1 to 12. This is to aid easy comparative analysis of the effect of VA solution on aluminium pipes and steel pipes.

Tab. 9. Data for WL and CR of Al Sample with $25 \%$ Inhibitor

\begin{tabular}{cccccc}
\hline Code & $\begin{array}{c}\text { Time } \\
\text { (hour })\end{array}$ & $\begin{array}{c}\text { Initial } \\
\text { weight } \\
(\mathrm{g})\end{array}$ & $\begin{array}{c}\text { Final } \\
\text { weight } \\
(\mathrm{g})\end{array}$ & $\begin{array}{c}\text { Change in } \\
\text { weight } \\
(\mathrm{g})\end{array}$ & $\begin{array}{c}\mathrm{CR} \\
(\mathrm{mm} / \mathrm{yr})\end{array}$ \\
\hline 5A1 & 168 & 2.8123 & 2.7036 & 0.1087 & 0.3236 \\
\hline 5A2 & 336 & 2.8123 & 2.7204 & 0.0919 & 0.1368 \\
\hline $5 \mathrm{~A} 3$ & 504 & 2.8123 & 2.7175 & 0.0948 & 0.0941 \\
\hline 5A4 & 672 & 2.8123 & 2.7003 & 0.1120 & 0.0834 \\
\hline $5 \mathrm{~A} 5$ & 840 & 2.8123 & 2.7001 & 0.1122 & 0.0668 \\
\hline
\end{tabular}

Tab. 10. Data for WL and CR of MS Samples with 25\% Inhibitor

\begin{tabular}{cccccc}
\hline Code & $\begin{array}{c}\text { Time } \\
(\text { hour })\end{array}$ & $\begin{array}{c}\text { Initial } \\
\text { weight } \\
(\mathrm{g})\end{array}$ & $\begin{array}{c}\text { Final } \\
\text { weight } \\
(\mathrm{g})\end{array}$ & $\begin{array}{c}\text { Change in } \\
\text { weight } \\
(\mathrm{g})\end{array}$ & $\begin{array}{c}\mathrm{CR} \\
(\mathrm{mm} / \mathrm{yr})\end{array}$ \\
\hline $5 \mathrm{~S} 1$ & 168 & 6.5976 & 6.5963 & 0.0013 & 0.0038 \\
\hline $5 \mathrm{~S} 2$ & 336 & 6.5976 & 6.5925 & 0.0051 & 0.0075 \\
\hline $5 \mathrm{~S} 3$ & 504 & 6.5976 & 6.5917 & 0.0059 & 0.0058 \\
\hline $5 \mathrm{~S} 4$ & 672 & 6.5976 & 6.5900 & 0.0076 & 0.0056 \\
\hline $5 \mathrm{~S} 5$ & 840 & 6.5976 & 6.5890 & 0.0086 & 0.0051 \\
\hline
\end{tabular}


Tab. 11. Data for WL and CR of Al Sample with $0 \%$ Inhibitor

\begin{tabular}{cccccc}
\hline Code & Time hour & $\begin{array}{c}\text { Initial } \\
\text { weight } \\
(\mathrm{g})\end{array}$ & $\begin{array}{c}\text { Final } \\
\text { weight } \\
(\mathrm{g})\end{array}$ & $\begin{array}{c}\text { Change in } \\
\text { weight } \\
(\mathrm{g})\end{array}$ & $\begin{array}{c}\mathrm{CR} \\
(\mathrm{mm} / \mathrm{yr})\end{array}$ \\
\hline 6A1 & 168 & 2.8465 & 2.7474 & 0.0991 & 0.8590 \\
\hline $6 \mathrm{~A} 2$ & 336 & 2.8465 & 2.6775 & 0.1690 & 0.7324 \\
\hline $6 \mathrm{~A} 3$ & 504 & 2.8465 & 2.6353 & 0.2112 & 0.6102 \\
\hline $6 \mathrm{~A} 4$ & 672 & 2.8465 & 2.6310 & 0.2455 & 0.5319 \\
\hline $6 \mathrm{~A} 5$ & 840 & 2.8465 & 2.5903 & 0.2562 & 0.4441 \\
\hline
\end{tabular}

Tab. 12. Data for WL and CR of MS Samples with 0\% Inhibitor

\begin{tabular}{cccccc}
\hline Code & Time hour & $\begin{array}{c}\text { Initial } \\
\text { weight } \\
(\mathrm{g})\end{array}$ & $\begin{array}{c}\text { Final } \\
\text { weight } \\
(\mathrm{g})\end{array}$ & $\begin{array}{c}\text { Change in } \\
\text { weight } \\
(\mathrm{g})\end{array}$ & $\begin{array}{c}\mathrm{CR} \\
(\mathrm{mm} / \mathrm{yr})\end{array}$ \\
\hline $6 \mathrm{~S} 1$ & 168 & 6.8217 & 6.6139 & 0.2078 & 0.6187 \\
\hline $6 \mathrm{~S} 2$ & 336 & 6.8217 & 6.6120 & 0.2097 & 0.3122 \\
\hline $6 \mathrm{~S} 3$ & 504 & 6.8217 & 6.5345 & 0.2872 & 0.2872 \\
\hline $6 \mathrm{~S} 4$ & 672 & 6.8217 & 6.5310 & 0.2907 & 0.2164 \\
\hline $6 \mathrm{~S} 5$ & 840 & 6.8217 & 6.5117 & 0.3100 & 0.1846 \\
\hline
\end{tabular}

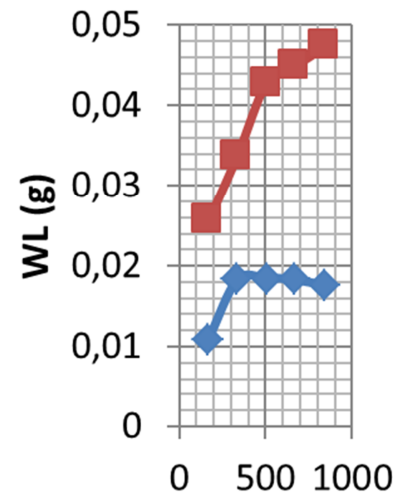

Time (hour)

Fig. 1. Combined Graph of WL against Time for 5\% Inhibitor

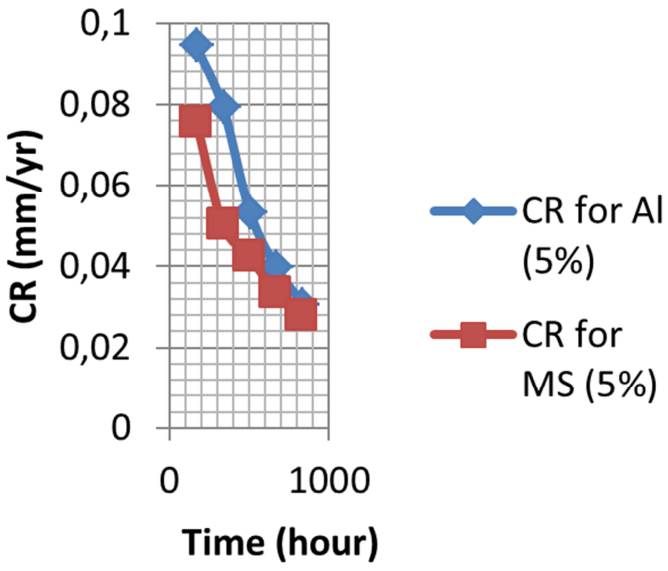

Fig. 2. Combined Graph of CR against time for coupons in $5 \%$ inhibitor solution

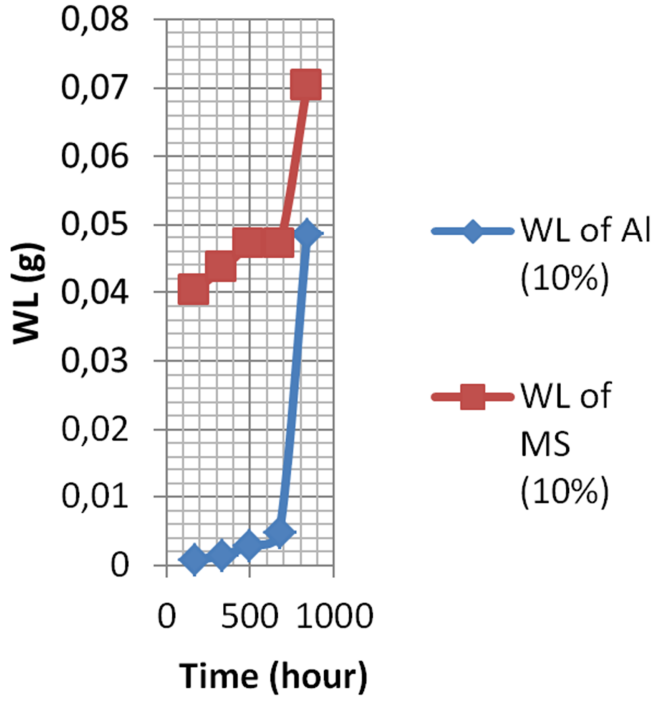

Fig. 3. Combined Graph of WL against Time for $10 \%$ Inhibitor

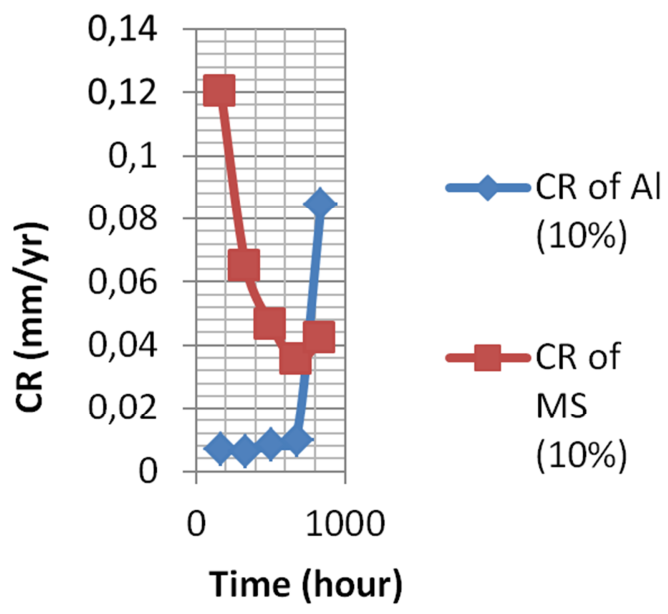

Fig. 4. Combined Graph of CR against time for coupons in $10 \%$ inhibitor solution

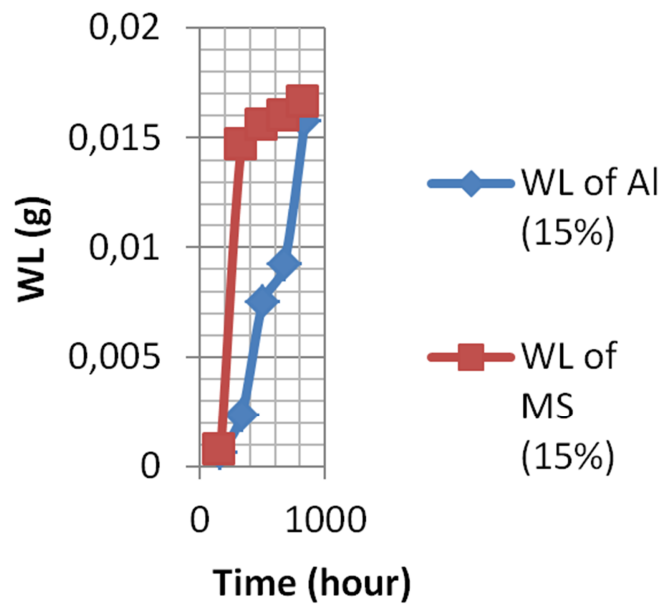

Fig. 5. Combined Graph of WL against Time for $15 \%$ Inhibitor 


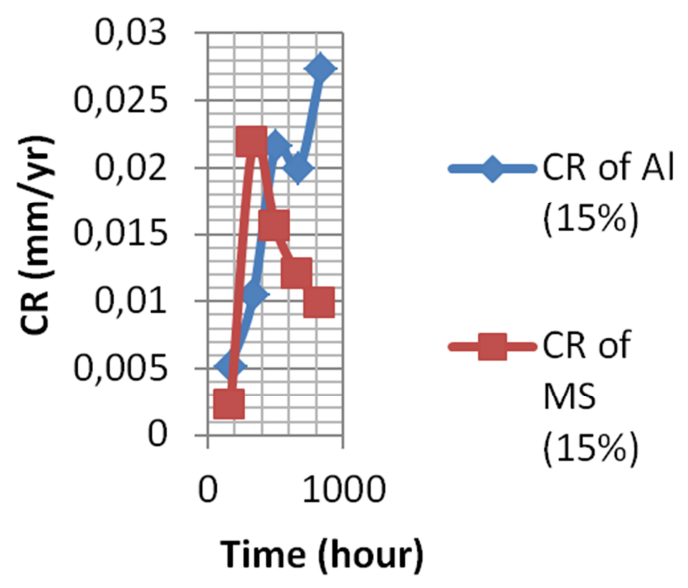

Fig. 6. Combined Graph of $\mathrm{CR}$ against time for coupons in $15 \%$ inhibitor solution

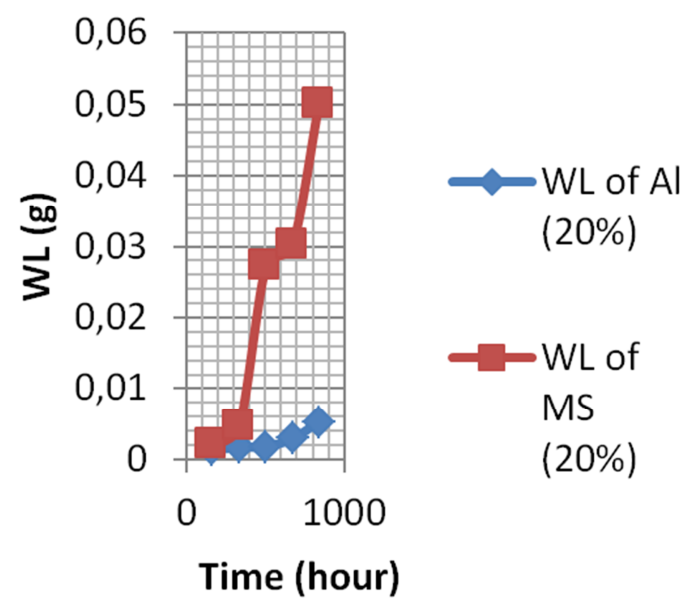

Fig. 7. Combined Graph of WL against Time for $20 \%$ Inhibitor

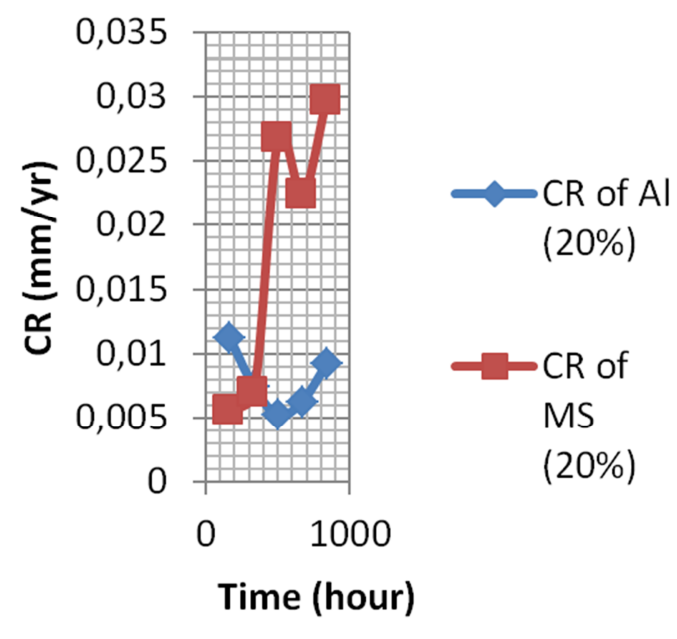

Fig. 8. Combined Graph of $\mathrm{CR}$ against time for coupons in $20 \%$ inhibitor solution

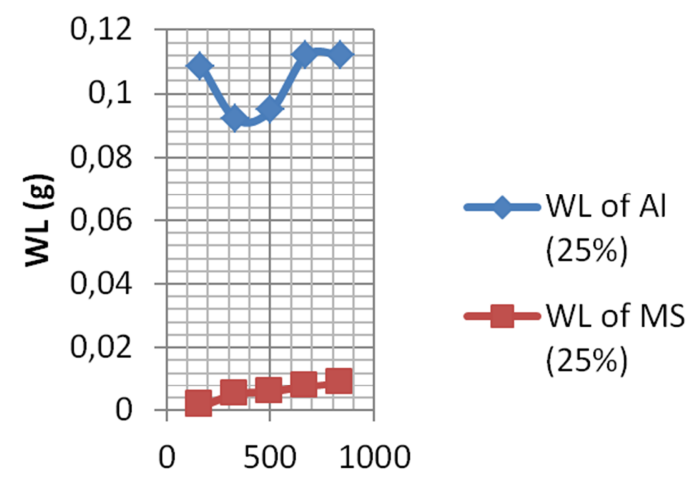

Time (hour)

Fig. 9. Combined Graph of WL against Time for $25 \%$ Inhibitor

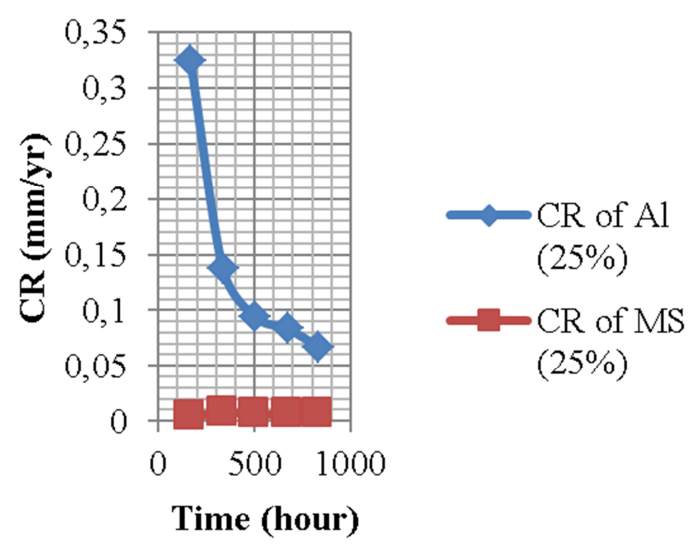

Fig. 10. Combined Graph of CR against time for coupons in $25 \%$ inhibitor solution

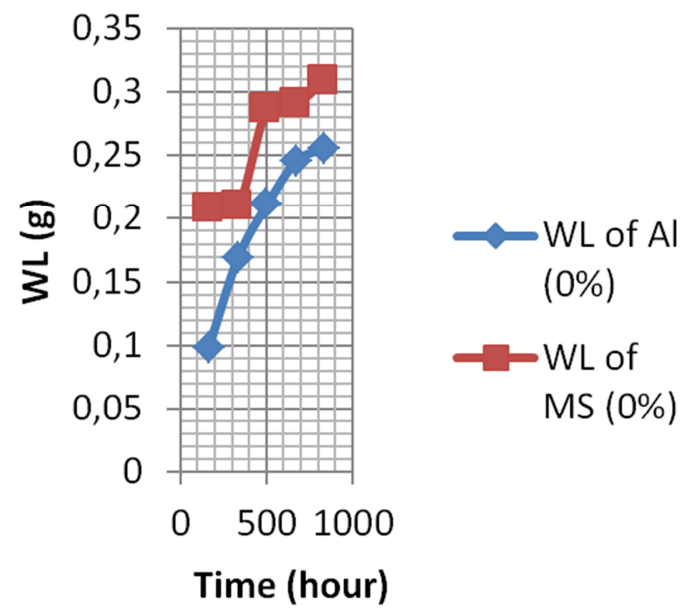

Fig. 11. Combined Graph of WL against Time for $0 \%$ Inhibitor 


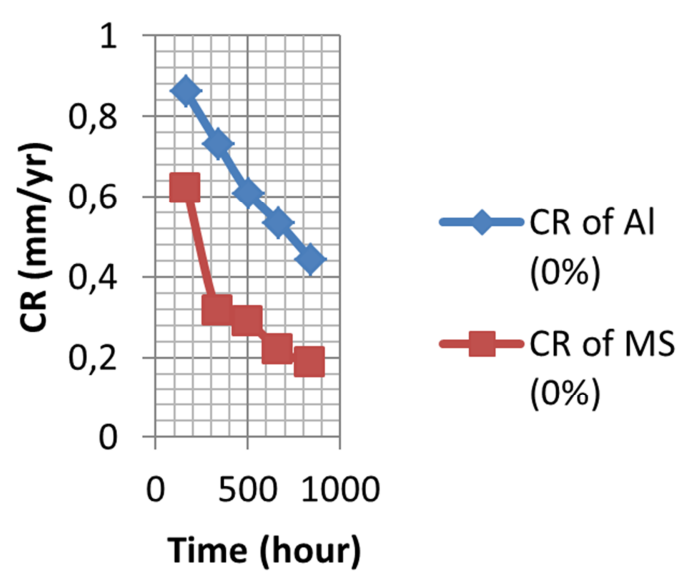

Fig. 12. Combined Graph of CR against time for coupons in $0 \%$ inhibitor solution

Figures 1 and 2 represent the graph of WL against time and $\mathrm{CR}$ against time for $\mathrm{Al}$ and $\mathrm{MS}$ samples with 5\% VA solution respectively. Figures 3 and 4 represent the graph of WL against time and CR against time for $\mathrm{Al}$ and $\mathrm{MS}$ samples with $10 \%$ VA solution respectively. Similarly Figures 5 and 6 represent the graph of WL against time and $\mathrm{CR}$ against time for $\mathrm{Al}$ and MS samples with $15 \%$ VA solution respectively. Figures 7 and 8 represent the graph of WL against time and $\mathrm{CR}$ against time for $\mathrm{Al}$ and MS samples with $20 \%$ VA solution respectively. Furthermore, Figures 9 and 10 represent the graph of WL against time and CR against time for $\mathrm{Al}$ and $\mathrm{MS}$ samples with $25 \% \mathrm{VA}$ solution respectively. Figures 11 and 12 serve as control and represent the graph of WL against time and $\mathrm{CR}$ against time for $\mathrm{Al}$ and MS samples with $0 \%$ VA solution respectively.

It is observed that the $\mathrm{WL}$ in $\mathrm{Al}$ is less compared to the MS when the VA solution is applied with 5\%. At 180 hours, the WL in $\mathrm{Al}$ and MS is given at about 0.0110 and 0.0260 respectively. While at 500 hours, the rate is given as 0.0185 and 0.0427 respectively. Similarly, we observed that the $\mathrm{CR}$ in $\mathrm{Al}$ is more compared to the MS, when the VA solution is applied with 5\%. At 180 hours, the $\mathrm{CR}$ in $\mathrm{Al}$ and MS is given at about 0.0960 and 0.0760 respectively. While at 500 hours, the rate is given as 0.0540 and 0.0430 respectively. It can be seen that at the first week of exposure to corrosive medium, there is a substantial reduction in weight of coupons, but over the next three weeks, there is a gradual decline in WL and the CR reduced evenly. The medium is inhibited and there is recognizable percentage of corrosion of coupons. It can be said that the percentage of inhibitor to corrosive medium (sea water) is insufficient. Figures 7 and 8 represent the graph of WL against time and CR against time for $\mathrm{Al}$ and MS samples with $20 \%$ inhibitor respectively. It is also observed that the $\mathrm{WL}$ in $\mathrm{Al}$ is less compared to the MS, when the VA solution is applied with $20 \%$. At 180 hours, the WL in Al and MS is given at about 0.0020 and 0.02080 respectively. While at 500 hours the rate is given as 0.027 and 0.2870 respectively. On the other hand, it is observed that the $\mathrm{CR}$ in $\mathrm{Al}$ is more at the initial, compared to the MS, when the VA solution is applied with $20 \%$, but later a change is noticed to be less as the hours count. At 180 hours, the $\mathrm{CR}$ in $\mathrm{Al}$ and MS is given at about 0.0110 and 0.0060 respectively. While at 500 hours, the rate is given as 0.0053 and 0.00260 respectively. So after the first 3 weeks of testing, there is a great decrease in CR. It shows that even with increase of percentage of inhibitor, the $\mathrm{CR}$ is not reducing accordingly. So a right percentage of inhibitor needs to be administered. Figures 11 and 12 represent the graph of WL against time and CR against time for $\mathrm{Al}$ and MS samples with $0 \%$ VA solution respectively. This is the control solution. The coupons are vulnerable to corrosion. WL determination has a number of attractive features that can account for its sustained popularity. Some of the advantages are simplicity in nature, because no sophisticated instrumentation is required to obtain a result. Secondly, it is direct, because a direct measurement is obtained, with no theoretical assumption or approximations. Thirdly, it is also versatile because it is applicable to all corrosive environments, and gives information on all forms of corrosion. Fourthly, it is visual because inspection can be undertaken. Furthermore, corrosion deposits can be observed and analyzed, weight loss can be readily determined and rate easily calculated. Additionally, localized corrosion can be identified, measured and inhibitor performance can be easily accessed on the transmission pipeline of $\mathrm{Al}$ and MS. This comparative analysis is also considered to know the effect of the VA solution measured by $10 \%, 15 \%$, and $25 \%$ on the two metals. This can be seen in Figures 3 and 4; 5 and 6; and 9 and 10 respectively.

\section{CONCLUSIONS}

When the VA solution is introduced into the marine environment, it neutralizes the chloride present in the medium. This action reduces the corrosion process of the coupons and this can be adopted in combating corrosion in $\mathrm{MS}$ and $\mathrm{AL}$ pipes for industrial purposes. This work, a comparative analysis of the effect of VA on subsea transmission pipeline shows the reaction on the MS and $\mathrm{Al}$ pipelines with respect to the WL and CR. As the hours and weeks go by, we observed different effect on the transmission pipelines. At the fifth week, the VA solution was gradually losing its effectiveness on the transmission pipeline. This means that more VA solution needs to be introduced at regular intervals to sustain the effectiveness of the inhibitor. It is also of vital interest to apply the right concentration of the VA solution since CR increases at high concentrations and temperature. A comparison of the graphs of $\mathrm{AI}$ and 
MS, indicates that a good tolerance of has been accommodated. From this research work, we can suggest that proper corrosion control programme should be adapted before pipelines installations. Monitoring techniques should also be continued during its useful lifespan. This is essential because this organic inhibitor loses its properties and become ineffective over time. It is also important that means of using this inhibitor on corrosive medium at high temperatures and velocities should be introduced, since this research was carried out at room temperature and zero flow rate conditions. Although the VA solution is cheap and easily available, they can possess disparities in their chemical composition because they are of make of various species. In view of this, their concentrations and inhibiting properties can differ. Therefore, comprehensive studies on these properties need to be conducted in future works for effective industrial applications. The results of this work could be of immense value to the $O \& G$ industries.

\section{References}

1. Aced students portal (2014). Wikipedia, 2005.

2. Alawode A.J., Ogunleye I.O. (2011). Maintenance, security and environmental implications of pipeline damage and ruptures in the niger delta Region. Pacific Journal of Science and Technology. Vol. 12, No. 1, pp. 565-573.

3. Samson N., Emmanuel U.O., Ezenwa A.O. (2018) Combating corrosion in transmission pipelines in marine environment using vernomia amydalina as inhibitor. Open Journal of Marine Science, Vol. 8, No. 4, pp. 450472.

4. Iduk U., Samson N. (2015). Effects and solutions of marine pollution from ships in nigerian waterways. International Journal of Scientific and Engineering Research, Vol. 6, No. 9, pp. $782-792$.

5. Ekine A.S., Emujakporue G.O. (2010). Investigation of corrosion of buried oil pipeline by the electrical geophysical methods. Journal of Applied Science and Environmental Management, Vol. 14, No. 1, pp. 63-65.

6. Sully J.R. Taylor D.W. (2004). Electrochemical Methods of Corrosion Testing Metals. ASM Handbook, Vol. 13a, Marcel Dekker, Inc., New York.

7. Standard Practice (2007). Control of external corrosion on underground or submerged metallic piping system. National Association of Corrosion Engineers International. https://www.nace.org/uploadedFiles/Corrosion_Central/I ndustries/SP016907PHMSA.pdf (accessed: November 2018).

8. Tuaweri T.J., Ogbonnaya A.O., Onyemaobi O.O (2015). Corrosion inhibition of heat treated mild steel with neem leaves extract in a chloride medium. International Journal of Research in Engineering and Technology, Vol. 4, No. 6, pp. 404-409.

9. Tuaweri T.J., and Ogbonnaya E.A. (2017). Corrosion Inhibition characteristics of Vernonia Amygdalina (Bitter leaf) Mild Steel in Seawater. Journal of Scientific and Engineering Research, Vol. 4, No. 11, pp. 6-13.

10. Osakuni M.U., Abam T.K. (2004). Shallow resistivity measurement for cathodic protection of pipelines in the Niger Delta. Journal of Environmental Geology, Vol. 45, No. 6, pp. 747-752.

\section{Biographical note}

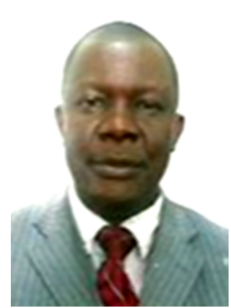

Samson Nitonye is a Lecturer in the Department of Marine Engineering of the Faculty of Engineering in the Rivers State University, Port Harcourt, Nigeria. $\mathrm{He}$ is a registered Engineer with the Council for the Regulation of Engineering in Nigeria (COREN) and a member of Nigerian Society of Engineers (NSE). He also lectures at the Center of Excellence in Marine and Offshore Engineering of the Rivers State University. He holds a Bachelor and Master's Degrees in Marine Engineering and he is currently a PhD student in Naval Architecture and Ship Building in the same University. His area of specialization includes amongst others; Ship Power Plant, Naval Architecture, Stability Analysis. He is also a member to some International bodies like SNAME, IMarEST, RINA and ASME. He is also a Bond Servant of God.

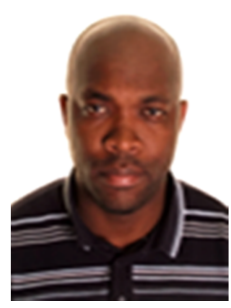

Thaddeus Chidiebere Nwaoha obtained his $\mathrm{PhD}$ in Marine and Offshore Technology and MSc in Marine and Offshore Engineering from Liverpool John Moores University, UK in 2011 and 2006 respectively. His professional experiences comprise of academic and industrial experiences in LNG carrier system maintenance and risk modeling, inspection of topside and subsea equipment, quality assurance, safety, risk and reliability analysis of marine and offshore systems. He has served as an inspection, quality assurance, safety and reliability engineer in marine and offshore companies and a member of professional bodies such as IMarEST, NSE and COREN. Since 2010, he has authored and co-authored more than 30 journal papers in world leading journals and one of his papers was nomination for SAGE 2011 best paper award in Journal of Engineering for Maritime Environment. His research interests are system failure analysis, design for safety of marine and offshore system, optimization, maintenance modelling and risk/ reliability analysis. Currently, he serves as a senior lecturer in Marine Engineering Department, Federal University of Petroleum Resources, Nigeria and marine/offshore risk engineering consultant for various companies.

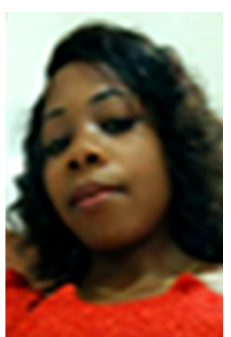

Umoh Ofonime Emmanuel holds a bachelor's degree in Marine Engineering from the Niger Delta University, Wilberforce Island, Bayelsa State. She is currently undergoing a master's degree at the Center of Excellence in Marine and Offshore Engineering of the Rivers State University, Port Harcourt, Nigeria 